\title{
POLA RESCHEDULING PADA PEMBIAYAAN BERMASALAH BERAKAD MURABAHAH DI BANK SYARIAH
}

\author{
Andini Salamah dan Arrison Hendry ${ }^{1.2}$
}

${ }^{12}$ Afiliasi: Sekolah Tinggi Ekonomi Islam SEBI.

Email: andinisalamah@gmail.com,arrison@inkopsyah.com

\begin{abstract}
ABSTRAK. Penelitian ini bertujuan untuk mengkaji lebih lanjut berkaitan dengan pembiayan bermasalah khususnya pada pembiayaan murabahah. Metode penelitian yang digunakan adalah pendekatan kualitatif dengan analisis deskriptif. Hasil penelitian ini adalah, proses rescheduling yang dilakukan bank syariah adalah memperpanjang jangka waktu pembiayaan dan angsuran, dengan kriteria nasabah meliputi: mengalami penurunan kemampuan membayar, memiliki prospek usaha yang baik, mampu memenuhi kewajiban setelah rescheduling. Kedua, bank syariah harus menerapkan ketentuan dari Fatwa DSN MUI yaitu tidak boleh menambah jumlah tagihan yang tersisa, pembebanan biaya dalam proses penjadwalan kembali adalah biaya riil, dan perpanjangan masa pembayaran harus didasarkan kesepakatan kedua belah pihak. Ketiga, dalam kasus pembiayaan bermasalah yang berlaku setelah penjadwalan ulang dilakukan, maka tindakan yang dapat dilakukan oleh bank syariah ialah mengkonversi akad pembiayaan murabahah menjadi pembiayaan qardh.
\end{abstract}

\section{Keywords: Rescheduling, Pembiayaan Bermasalah, Murabahah, Bank Syariah}

\begin{abstract}
This study aims to examine further related to problem financing, especially in murabahah financing. The research method used is a qualitative approach with descriptive analysis. The results of this study are, the rescheduling process undertaken by Islamic banks is to extend the term of financing and installment, with customer's critera: decreased ability to pay, has a good business prospect, able to fulfill obligations after rescheduling. Second, Islamic bank must apply the provisions of the Fatwa DSN MUI that should not add to the remaining amount of bills, charging the cost in the rescheduling process is the real cost, and the extension of time payer must based on the agreement of both parties. Third, in the case of problem financing in effect after rescheduling is done, then the action that can be performed by the Islamic bank is to convert the murabahah financing contract into the qardh financing agreement.
\end{abstract}

Keywords: Rescheduling, Financing Problematic, Murabahah, Islamic Bank

\section{PENDAHULUAN}

Di Indonesia, sejak dikeluarkannya Undang Undang (UU) Perbankan dan Undang Undang (UU) No. 23 tahun 1999 tentang Bank Indonesia sebagaimana telah diubah dengan UU No. 3 tahun 2004 yang mengakomodasi perbankan syariah, maka sejak tahun 1998 perbankan syariah nasional berkembang cukup pesat, baik aset maupun kegiatan usahanya (Wangsawidjaja, 2012)

Setelah itu, yang terakhir dikeluarkannya UU Nomor 21 Tahun 2008 tentang Perbankan Syariah (selanjutnya disebut UU Perbankan Syariah). 


\section{8 | Andini Salamah: Pola Resecheduling Pada Pembiayaan Bermasalah Berakad Murabahah Di Bank Syariah}

Dalam UU Perbankan Syariah tersebut pada pasal 1 angka 1, yang dimaksud perbankan syariah adalah segala sesuatu yang menyangkut tentang Bank Umum Syariah (BUS) dan Unit Usaha Syariah (UUS), mencakup kelembagaan, kegiatan usaha, serta cara dan proses dalam melaksanakan kegiatan usahanya. Adapun perkembangan total aset dan pembiayaan perbankan syariah tersebut dapat digambarkan sebagai berikut:

Tabel 1.1. Kegiatan Usaha Bank Umum Syariah dan Unit Usaha Syariah (dalam miliar rupiah)

\begin{tabular}{|l|l|l|l|l|}
\hline Keterangan & $\mathbf{2 0 1 4}$ & $\mathbf{2 0 1 5}$ & $\mathbf{2 0 1 6}$ & $\mathbf{2 0 1 7}$ \\
\hline Total Aset & 272.343 & 296.262 & 356.504 & 378.198 \\
\hline Pembiayaan & 199.330 & 212.996 & 248.007 & 265.317 \\
\hline
\end{tabular}

Sumber: Data diolah dari OJK, Statistik Perbankan Syariah, Juni 2017

Berdasarkan data di atas, tingkat perkembangan perbankan syariah nasional mencapai kemajuan yang cukup pesat dan mengalami kenaikan angka disetiap tahunnya (tahun 2008 sampai dengan tahun 2011) baik dari segi aset maupun pembiayaan. Oleh karena itu, perbankan syariah memiliki kedudukan yang strategis untuk turut menggerakkan sektor riil dalam rangka meningkatkan perekonomian khususnya ekonomi syariah dan pembangunan di Indonesia.

Dalam UU Perbankan Syariah Nomor 21 Tahun 2008 pasal 4 menjelasakan bahwa bank syariah merupakan lembaga keuangan yang berfungsi sebagai perantara bagi pihak berlebihan dana dan pihak kekurangan dana untuk kegiatan usaha dan kegiatan lainnya yang sesuai dengan hukum Islam. Jenis usaha bank syariah ini sebagai lembaga keuangan perantara secara sederhana dapat dijalankan salah satunya berupa pembiayaan.

Pembiayaan merupakan salah satu fungsi bank dalam menjalankan aktivitas penyaluran atau penggunaan dana. Menurut UU Perbankan No. 10 Tahun 1998, pembiayaan adalah penyediaan uang atau tagihan yang dapat dipersamakan dengan itu, berdasarkan persetujuan atau kesepakatan antara bank dan pihak lain yang dibiayai untuk mengembalikan uang atau tagihan tersebut setelah jangka waktu tertentu dengan imbalan atau bagi hasil.

Dari pengertian pembiayaan tersebut, dapat dijelaskan bahwa tujuan pembiayaan adalah untuk menambah modal usaha, baik kredit atau pembiayaan dapat berupa uang atau tagihan yang nilainya diukur dengan uang, selain itu juga untuk meningkatkan pendapatan atau perolehan keuntungan dari penyaluran pembiayaan. Sejalan dengan hal tersebut, tingkat risiko yang ditimbulkan juga tinggi. Oleh karena itu, penerapan manajemen risiko atas pembiayaan yang disalurkan sangat diperlukan.

Salah satu bentuk pembiayaan yang selalu mengalami peningkatan jumlah penyaluran setiap tahunnya adalah pembiayaan murabahah. Murabahah didefinisikan oleh para fuqoha sebagai penjualan barang seharga biaya atau harga pokok barang tersebut ditambah keuntungan (margin) yang disepakti. Produk murabahah ini merupakan salah satu bentuk pembiayaan 
Jurnal Ekonomi dan Perbankan Syariah

Vol. 6. No.1, April 2018: 27-48, ISSN (cet): 2355-1755 | ISSN (online): 25796437

| 29

berprinsip jual beli yang paling dominan diterapkan dalam praktik perbankan syariah.

Grafik 1.1. Statistika Pembiayaan Murabahah Pada Bank Umum Syariah dan Unit Usaha Syariah di Indonesia

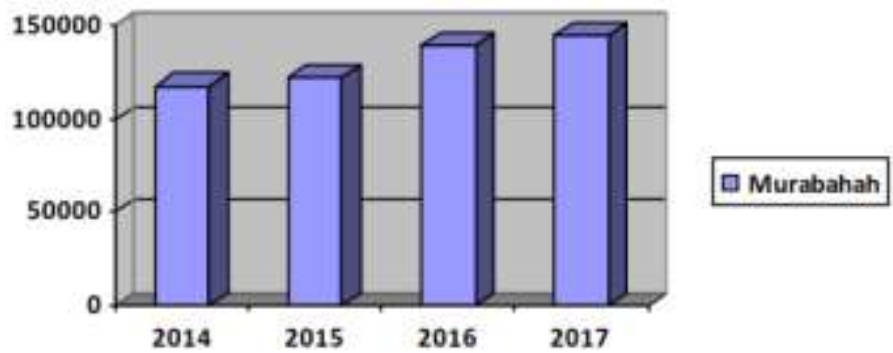

Sumber: Data diolah dari OJK - Statistik Perbankan Syariah, Juni 2017

Dari di atas dapat dijelaskan bahwa produk pembiayaan murabahah pada tahun terakhir yaitu tahun 2014 sampai dengan tahun 2017 bulan Juni mengalami kenaikan. Meningkatnya angka pada produk pembiayaan murabahah ini menunjukakan bahwa pembiayaan tersebut mempunyai banyak keuntungan bagi bank maupun masyarakat.

Antara pihak bank dengan nasabah debitur, sebelum melakukan transaksi pembiayaan murabahah ini selalu membuat kesepakatan yang disetujui oleh kedua pihak sebelumnya, dan kesepakatan tersebut tertulis dalam akad pembiayaan. Dengan demikian, secara otomatis kedua pihak telah terikat oleh perjanjian dan hukum yang telah dibuat bersama. Akad yang dilakukan pada bank syariah ini yaitu akad pembiayaan dan akad dengan notaris untuk mengikat jaminan yang diberikan nasabah kepada bank syariah (Hilyatin, 2016, hlm. 62). Hal tersebut dilakukan oleh bank syariah sebagai salah satu upaya agar pihak bank dapat terhindar dari pembiayaan bermasalah yang mungkin terjadi dikemudian hari.

Namun, nasabah yang menggunakan pembiayaan murabahah tersebut dalam pelaksanaan angsuran pembiayaan sangat variatif, ada yang tepat waktu, ada juga yang lebih awal dari waktu yang telah ditentukan bahkan ada yang tidak tepat waktu pembayaran pembiayaannya, akan tetapi terdapat mitra yang membayar angsurannya tidak sesuai dengan waktu yang telah disepakati sehingga bisa dikatakan nasabah tersebut bermasalah. Apabila didasarkan pada ketentuan yang dikeluarkan oleh Bank Indonesia, maka pihak bank harus menjaga jumlah pembiayaan bermasalah yang dimilikinya tidak lebih dari $5 \%$ (Hilyatin, 2016, hlm. 63).

Berikut ini data mengenai jumlah pembiayaan bermasalah yang terjadi pada pembiayaan murabahah di perbankan syariah: 
30 | Andini Salamah: Pola Resecheduling Pada Pembiayaan Bermasalah Berakad Murabahah Di Bank Syariah

Tabel 1.2. Tingkat NPF dan Pembiayaan Murabahah pada Bank Umum

Syariah dan Unit Usaha Syariah (dalam miliar rupiah)

\begin{tabular}{|l|l|l|l|l|}
\hline \multicolumn{1}{|c|}{ Indikator } & $\mathbf{2 0 1 4}$ & $\mathbf{2 0 1 5}$ & $\mathbf{2 0 1 6}$ & $\mathbf{2 0 1 7}$ \\
\hline Murabahah & 117.371 & 122.111 & 139.536 & 145.004 \\
\hline NPF & 4.844 & 5.502 & 6.258 & 6.946 \\
\hline$\%$ & $4.13 \%$ & $4.51 \%$ & $4.48 \%$ & $4.79 \%$ \\
\hline
\end{tabular}

Sumber : Data diolah dari OJK - Statistik Perbankan Syariah, Juni 2017

Dengan memperhatikan di atas, maka dapat disimpulkan bahwa upaya atau strategi yang digunakan oleh BUS dan UUS di Indonesia dalam menangani pembiayaan bermasalah yang berakad murabahah sudah efektif, karena jumlah pembiayaan bermasalah tidak melebihi ketentuan yang telah ditetapkan oleh Bank Indonesia.

Secara umum, kasus pembiayaan bermasalah tidak terjadi secara tibatiba (macet), namun akan mengalami beberapa tahap (proses). Pada tahap proses (pembiayaan bermasalah) tersebut pihak bank akan memberikan peringatan kepada nasabah secara kekeluargaan, apabila nasabah tersebut masih saja mengalami kesulitan untuk menyelesaikan kewajibannya, maka dengan persetujuan dari pihak nasabah dapat dilakukan upaya restrukturisasi pembiayaan.

Dijelaskan dalam Peraturan Bank Indonesia (PBI) Nomor 13/9/PBI/2011 bahwa restrukturisasi pembiayaan adalah upaya dilakukan bank dalam rangka membantu nasabah agar dapat menyelesaikan kewajibannya, antara lain melalui: penjadwalan kembali (rescheduling), persyaratan kembali (reconditioning), dan penataan kembali (restructuring). Ketiga hal tersebut digunakan untuk Bank Syariah dan Unit Usaha Syariah dalam melakukan penyehatan dan penyelamatan pembiayaan bermasalah yaitu dengan cara melakukan rescheduling, reconditioning dan restructuring (3R).

Dari latar belakang masalah di atas, penulis ingin mengetahui dan tertarik untuk melakukan kajian lebih lanjut bagaimana penyehatan pembiayaan bermasalah dengan cara langkah rescheduling khususnya pada pembiayaan berakad murabahah. Oleh karena itu, penelitian ini diambil dengan judul "Pola Rescheduling Pada Pembiayaan Bermasalah Berakad Murabahah di Bank Syariah".

\section{LANDASAN TEORI}

\subsection{Rescheduling}

Dalam PBI No. 13/9/PBI/2011 tentang perubahan atas Peraturan Bank Indonesia No. 10/18/PBI/2008 tentang Restrukturisasi Pembiayaan Bagi Bank Syariah dan Unit Usaha Syariah, penjadwalan kembali (rescheduling) yaitu perubahan jadwal pembayaran kewajiban nasabah atau jangka waktunya.

Rescheduling menurut Thomas Suyatno (2007, hlm. 108) yaitu memperpanjang jangka waktu pembiayaan, memperpanjang jarak waktu 
Jurnal Ekonomi dan Perbankan Syariah

Vol. 6. No.1, April 2018: 27-40, ISSN (cet): 2355-1755 | ISSN (online): 25796437

\section{| 31}

angsuran dan penurunan jumlah untuk setiap angsuran yang mengakibatkan perpanjangan waktu pembiayaan.

Resceduling atau penjadwalan ulang adalah perubahan syarat kredit yang menyangkut jadwal pembayaran atau jangka waktu termasuk masa tenggang dan perubahan besarnya angsuran kredit (.S.P.Hasibuan, 2009, hlm. 115). Debitur yang dapat diberikan fasilitas penjadwalan ulang adalah nasabah yang menunjukkan itikad baik dan karakter yang jujur serta ada keinginan untuk membayar serta menurut bank, usahanya tidak memerlukan tambahan dana atau likuiditas.

Dari pengertian rescheduling tersebut, dapat disimpulkan bahwa rescheduling merupakan penyelamatan pembiayaan dengan menjadwal ulang jangka waktu pembayaran, yang pada umumnya dilakukan adalah perpanjangan jangka waktu dengan tujuan angsuran nasabah lebih kecil disesuaikan dengan kemampuan nasabah tersebut.

Didalam teori hukum perbankan, menurut Thamrin Abdullah (2012, hlm. 181) rescheduling dilakukan atas itikad baik kreditur kepada debitur yang fungsinya adalah sebagai berikut:

1. Melalui rescheduling diharapkan kreditur dapat membantu mengentaskan dari keterpurukan ekonomi mitra kerja.

2. Melalui rescheduling kreditur dapat mewujudkan kesejahteraan mitra kerjanya.

3. Dengan rescheduling harapannya beban ekonomi yang ditanggung oleh mitra kerja berkurang.

4. Melalui rescheduling sebagai upaya nyata untuk menghindari kerugian bagi debitur.

Landasan syar'i rescheduling terdapat dalam Q.S. Al-Baqarah [2] : 280 sebagai berikut:

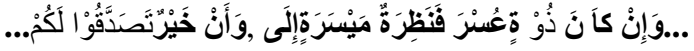

Artinya: "... Dan jika (orang berutang itu) dalam kesukaran, maka berilah tangguhan sampai dia berkelapangan. Dan menyedekahkan (sebagian atau semua utang) itu lebih bik bagimu, jika kamu mengetahui." (Q.S. Al-Baqarah [2] : 280).

Ayat tersebut merupakan lanjutan ayat yang sebelumnya. Ayat yang lalu memerintahkan agar orang yang beriman menghentikan perbuatan riba setelah turun ayat diatas. Maka ayat ini menerangkan bahwa jika pihak berutang itu dalam kesukaran berilah dia tempo, hingga dia sanggup membayar utangnya. Sebaliknya jika yang berutang dalam keadaan lapang, dia wajib segera membayar utangnya (RI, 2009). Kemudian, dalam tafsirnya AlQurthubi, 3/371 menyebutkan, ayat ini turut terkait kasus yang dialami Bani Tsaqif dengan Bani Al-Mughirah untuk melunasi utangnya, mereka belum belum sanggup membayarnya. Mereka mengaku tidak memiliki apapun untuk dibayarkan, dan meminta waktu tunda sampai musim panen, kemudian turun ayat ini. 
Berbeda halnya dengan aturan dimasa jahiliyah, orang yang berutang dan dia tidak bisa membayar sampai batas yang ditetapkan, maka dia harus menjual dirinya untuk menjadi budak, agar bisa melunasi utangnya. Kemudian aturan tersebut dinasakh dalam Islam. Sebagian ulama mengatakan, pilihan memberi waktu tenggang bagi orang yang tidak mampu melunasi utangnya adalah sifatnya wajib (Baits, 2015)

\subsection{Pembiayaan Bermasalah}

Pembiayaan bermasalah adalah salah satu bentuk risiko yang pasti ada dan dihadapi oleh setiap bank karena setiap anggota memiliki kekurangan ketika melakukan pengembalian pembiayaan kepada bank. Setiap bank dalam memberikan pembiayaan harus memperhatikan beberapa prinsip utama apakah nasabah layak untuk diberikan pembiayaan atau tidak. Penilaian suatu bank untuk memberikan persetujuan terhadap suatu permohonan pembiayaan dilakukan dengan berpedoman kepada formula 5C (character, capacity, capital, collateral, condition) (Hermansyah, 2011, hlm. 63).

Menurut Rivai dalam penelitiannya Nur Eka dan Made Dudy (2014), yang dimaksud dari 5C tersebut adalah sebagai berikut:

1. Character (watak), merupakan ukuran untuk menilai "kemauan" nasabah membayar kreditnya. Orang yang memiliki karakter baik akan berusaha untuk membayar kreditnya dengan berbagai cara. Dalam kenyataannya untuk menilai nasabah tidaklah mudah dan dibutuhkan waktu yang lama. Hal-hal tersebut diatas merupakan suatu ukuran tentang willingness to pay (kemauan untuk membayar).

2. Capacity (kemampuan), untuk melihat kemampuan nasabah dalam bidang bisnis serta yang dihubungkan dengan kemampuannya mengelola bisnis serta kemampuannya mencari laba.

3. Capital (modal), modal adalah modal usaha dari calon debitur yang telah tersedia atau telah ada sebelum mendapatkan fasilitas kredit.

4. Condition, kondisi ekonomi yang diperhatikan tidak saja mengenai kondisi ekonomi pada setiap usaha calon nasabah tetapi juga kondisi ekonomi secara umum dimana perusahaan calon debitur itu berada.

5. Collateral (Jaminan), merupakan jaminan atau agunan yang diberikan oleh calon debitur. Jaminan ini bersifat sebagai jaminan tambahan, karena jaminan utama kredit adalah pribadi calon debitur dan usahanya. Jaminan merupakan bentuk terakhir bagi keselamatan kredit.

Faktor penyebab pembiayaan bermasalah terdapat dua faktor, yaitu faktor internal dan faktor eksternal. Maksudnya dari kedua faktor tersebut adalah faktor eksternal itu disebabkan oleh faktor kesengajaan dan faktor ketidaksengajaan, sedangkan faktor internal adalah kurang teliti bank dalam menganalisis calon nasabah yang meminta pembiayaan. Ketika masalah pembiayaan macet ini muncul, maka dapat diprediksi melalui keterlambatan nasabah dalam melakukan pembayaran. Keterlambatan ini dapat menyimpulkan apakah nasabah ini memang sengaja tidak ingin membayar atau memang tidak mampu membayar. Ketidakmampuan disini pun yaitu berupa 
Jurnal Ekonomi dan Perbankan Syariah

Vol. 6. No.1, April 2018: 27-40, ISSN (cet): 2355-1755 | ISSN (online): 2579-

6437

33

sesuatu hal yang diluar perkiraan (bencana) atau gagal usaha (Ali, 2015, hlm. 11)

Sedangkan menurut Hilyatin (2016), penyebab timbulnya suatu pembiayaan bermasalah terdiri dari faktor internal dan eksternal perbankan (hlm. 66). Faktor internal dan faktor eksternal perbankan tersebut dapat diuraikan sebagai berikut:

1. Faktor Internal Perbankan

Yaitu penyebab pembiayaan bermasalah yang berasal dari dalam bank itu sendiri, diantaranya:

- Kualitas pejabat bank

- Persaingan antar bank

- Hubungan ke dalam; maksudnya adalah hubungan bank dengan perusahaan lain yang tergabung dalam kelompoknya, serta hubungan bank dengan pengurus maupun dengan pemegang saham.

- Pengawasan; tindakan pengawasan dilakukan oleh pihak bank itu sendiri dan pihak Bank Indonesia.

2. Faktor Eksternal Perbankan

Pembiayaan bermasalah disebabkan oleh nasabah pembiayaan, seperti nasabah yang menggunakan dana tidak sesuai dengan ketentuan akad, nasabah beritikad tidak baik, tidak jujur, lalai, dan lain sebagainya. Dapat pula diidentifikasi penyebab timbulnya pembiyaan bermasalah antara lain karena perubahan politik dan peraturan perundangan, deregulasi sektor riil, keuangan dan ekonomi.

\subsection{Akad Murabahah}

Akad murabahah dijelaskan dalam Peraturan Bank Indonesia (PBI) Nomor 7 Tahun 2005 pasal 1 tentang Akad Penghimpunan dan Penyaluran Dana Bagi Bank yang Melaksanakan Kegiatan Usaha Berdasarkan Prinsip Syariah, bahwa murabahah adalah jual beli barang sebesar harga pokok barang ditambah dengan margin keuntungan yang disepakati.

Sedangkan dalam Surat Edaran Otoritas Jasa Keuangan (SE OJK) Nomor 36/SEOJK/2015 Lampiran IV tentang Produk dan Aktivitas Bank Umum Syariah dan Unit Usaha Syariah, yang menjelaskan pembiayaan murabahah merupakan penyediaan dana atau tagihan yang dapat dipersamakan dengan itu untuk transaksi jual beli barang sebesar harga pokok ditambah margin berdasarkan persetujuan atau kesepakatan antara bank dengan nasabah yang mewajibkan nasabah untuk melunasi utang/kewajibannya.

Selain PBI dan SE OJK, Habibi Ahmed (2014) juga menyatakan, “ murabahah is a sale contract at a mark-up. The seller adds a profit component (mark-up) to the cost of the item being sold," (hlm. 18)

Dari ketiga pengertian diatas, dapat disimpulkan bahwa akad murabahah adalah akad jual beli atas barang tertentu, dimana penjual (bank) menyebutkan dengan jelas barang yang diperjual belikan, termasuk harga 
pembelian barang kepada pembeli (nasabah), kemudian ia mensyaratkan atasnya laba atau keuntungan dalam jumlah tertentu.

Landasan syar'i akad murabahah terdiri dari:

1. Firman Allah Q.S. Al-Baqarah [2] : 275 :

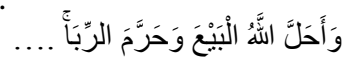

Artinya: “...dan Allah telah menghalalkan jual beli dan mengharamkan riba..." (Q.S. Al-Baqarah [2] : 275)

2. Firman Allah Q.S. Al-Maidah [5] : 1 :

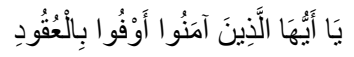

Artinya: "Hai Orang yang beriman! Penuhilah akad-akad itu..."

(Q.S. Al-Maidah [5] : 1)

3 Hadits Nabi riwayat Ibnu Majah:

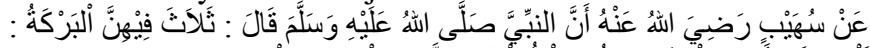

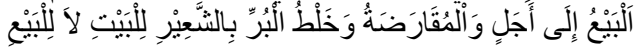

Artinya: "Dari Suhaib ar-Rumi r.a Nabi bersabda: ada 3 hal yang mengandung berkah: jual beli tidak secara tunai, muqaradah (mudharabah), dan mencamput gandum dengan jewawut untuk keperluan rumah tangga, bukan untuk dijual." (H.R. Ibnu Majah dari Shuhaib)

Dalam pembiayaan berdasarkan akad murabahah, bank bertindak sebagai pihak penyedia dana dalam kegiatan transaksi murabahah dengan nasabah. Bank dapat membiayai sebagian atau seluruh harga pembelian barang yang telah disepakati kualifikasinya. Apabila telah ada kesepakatan antara bank dan nasabahnya, dan akad pembiayaan murabahah telah ditandatangani oleh bank dan nasabah, maka bank wajib menyediakan dana untuk merealisasikan penyediaan barang yang dipesan nasabah.

Dalam pembiayaan murabahah, bank dapat memberikan potongan/diskon dengan besar yang wajar tanpa diperjanjikan dimuka. Dalam praktik, potongan tersebut diberikan oleh bank apabila nasabah melunasi utang murabahah lebih awal dari pada jangka waktu akad pembiayaan (Wangsawidjaja, 2012, hlm. 201)

Dalam fatwa DSN No. 04/DSN-MUI/IV/2000 tentang Murabahah, antara lain ditegaskan bahwa jaminan dalam murabahah dibolehkan, agar nasabah serius dengan pesanannya. Bank dapat meminta nasabah untuk menyediakan jaminan yang dapat dipegang. Karena barang yang dijual oleh bank kepada nasabah sejak akad sudah menjadi milik nasabah dan dapat dibalik nama atas nasabah yang bersangkutan, maka barang yang dibiayai dengan fasilitas pembiayaan berdasarkan akad pembiayaan murabahah tersebut merupakan agunan pokok yang dapat diikat sesuai ketentuan yang berlaku, misalnya hak tanggungan, jaminan fidusia, atau gadai.

Dalam praktik, fasilitas pembiayaan berdasarkan akad murabahah diberikan dalam bentuk penyediaan dana di rekening pembiayaan atas nama nasabah penerima fasilitas oleh bank syariah. Pada saat pencairan untuk pembelian barang dari produsen/supplier, bank syariah mendebit rekening pembiayaan atas nama nasabah dan mengkredit rekening giro atau rekening tabungan atas nama nasabah. 
Jurnal Ekonomi dan Perbankan Syariah

Vol. 6. No.1, April 2018: 27-48, ISSN (cet): 2355-1755 | ISSN (online): 2579 6437

| 35

Bank syariah melakukan pembayaran kepada produsen/supplier sejumlah harga barang lazimnya dengan mendebit rekening giro atau rekening tabungan atas nama nasabah dan mengkredit rekening produsen/supplier. Selanjutnya, produsen/supplier menyerahkan barang yang dibiayai, langsung kepada nasabah.

Apabila nasabah tidak diwajibkan membuka rekening giro atau rekening tabungan untuk menampung pencairan dana pembiayaan, maka pada saat pencairan, bank syariah akan mendebit rekening pembiayaan atas nama nasabah dan mengkredit rekening produsen/supplier. Saldo debit rekening pembiayaan (outstanding pembiayaan) merupakan salah satu bukti adanya utang murabahah nasabah kepada bank syariah yang wajib dilunasi setelah jangka waktu tertentu atau pada saat jatuh tempo pembiayaan sesuai yang telah disepakati dalam akad pembiayaan.

Dalam Surat Edaran Bank Indonesia (SE BI) No. 5/26/BPS tentang Piutang Murabahah (Pedoman Akuntansi Perbankan Syariah Indonesia 2003), transaksi pembiayaan berdasarkan akad murabahah, proses pengadaan barang (aktiva) murabahah harus dilakukan oleh bank sebagai penjual. Karena bank bertindak sebagai penjual, berarti kepemilikan atas barang ada pada bank. Permasalahan yang timbul adalah apakah kepemilikan bank atas barang tersebut dilakukan secara riil atau berlaku sebagai prinsip saja.

Berikut adalah skema pembiayaan berdasarkan akad murabahah yang dilakukan di bank syariah:

Bagan 2.1. Skema Pembiayaan Murabahah

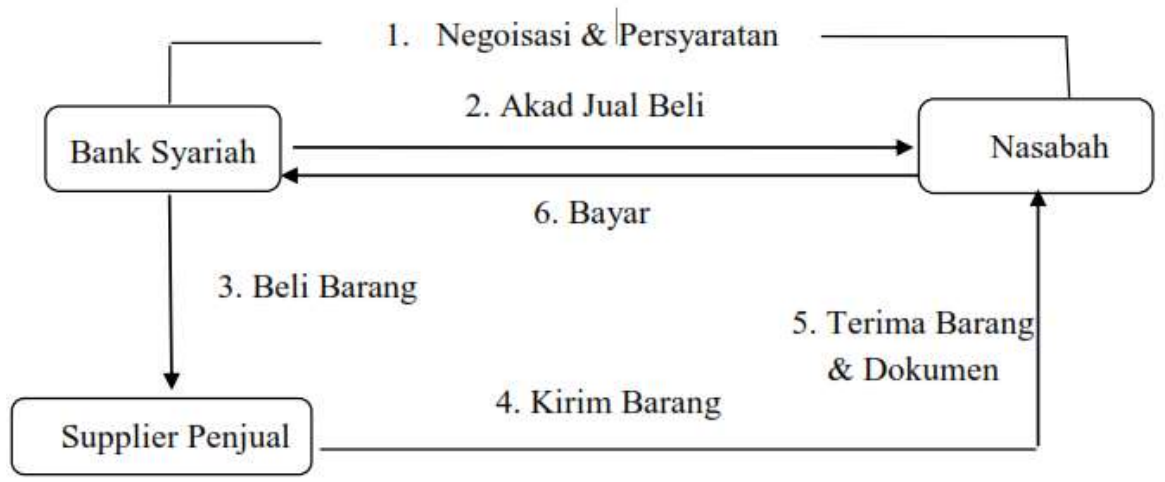

Keterangan:

Sumber: Ismail, Perbankan Syariah, 2011.

1. Bank syariah dan nasabah melakukan negoisasi tentang rencana transaksi jual beli yang akan dilaksanakan. Poin negoisasi meliputi jenis barang yang akan dibeli, kualitas barang, dan harga jual.

2. Bank syariah melakukan akad jual beli dengan nasabah, dimana bank syariah sebagai penjual dan nasabah sebagai pembeli. Dalam akad jual beli ini, ditetapkan barang yang menjadi objek jual beli yang telah dipilih oleh nasabah, dan harga jual barang. 
3. Atas dasar akad yang dilaksanakan antara bank syariah dan nasabah, maka bank syariah membeli barang dari supplier/penjual. Pembelian yang dilakukan oleh bank syariah ini sesuai dengan keinginan nasabah yang telah tertuang dalam akad.

4. Supplier mengirimkan barang kepada nasabah atas perintah bank syariah.

5. Nasabah menerima barang dari supplier dan menerima dokumen kepemilikan barang tersebut.

6. Setelah menerima barang dan dokumen, maka nasabah melakukan pembayaran. Pembayaran yang lazim dilakukan oleh nasabah ialah dengan cara angsuran.

\section{METODE PENELITIAN}

Penelitian ini dilakukan dengan menggunakan pendekatan kualitatif dan dengan menggunakan metode analisis deskriptif. Penelitian dengan pendekatan kualitatif adalah sebuah teknik interpretasi yang bertujuan menjelaskan, mengartikan, dan menerjemahkan suatu fenomena sosial menjadi suatu istilah atau pengetahuan yang memiliki makna dan dapat dimengerti. Sedangkan metode analisis deskriptif adalah metode analisis yang bertujuan mendeskripsikan atau menjelaskan sesuatu apa adanya. Jenis data yang digunakan dalam penelitian ini adalah data sekunder. Data sekunder merupakan sumber data yang tidak langsung memberikan data kepada pengumpul data (Sugiono, 2009). Teknik pengumpulan data merupakan cara yang dilakukan peneliti untuk memperoleh data. Data sekunder dengan menggunakan kajian literatur atau studi kepustakaan. Studi pustaka dilakukan untuk memperoleh teori-teori relavan yang diperoleh dengan cara membaca dan mempelajari baik berupa buku, artikel, jurnal, ataupun dari hasil penelitian terdahulu yang ada kaitannya dengan penelitian.

\section{PEMBAHASAN}

\subsection{Pokok-Pokok Ketentuan Rescheduling Pebiayaan Bermasalah Berakad Murabahah}

Dalam penelitian Maulidizen dan Taqiuddin (2017, hlm. 176) perihal Penjadwalan Ulang (rescheduling) Pembiayaan Murabahah di Bank Syariah, terdapat pokok-pokok ketentuan yang harus dilakukan oleh bank dan nasabah dalam melakukan rescheduling pada pembiayaan bermasalah berakad murabahah di bank syariah, diantaranya yaitu:

1. Penjadwalan ulang pembiayaan dapat dilakukan untuk pembiayaan dengan kualitas:
a. Lancar (gol. I)
b. Dalam Perhatian Khusus (gol. II)
c. Kurang Lancar (gol. III)
d. Diragukan (gol. IV)
e. Macet (gol. V) 
5. Pembiayaan yang dapat dilakukan penjadwalan ulang harus memenuhi kriteria sebagai berikut:

a. mengalami penurunan kemampuan membayar;

b. memiliki prospek usaha yang baik;

c. mampu memenuhi kewajiban setelah penjadwalan ulang.

6. Pelaksanaan penjadwalan ulang harus didasarkan adanya surat permohonan dari nasabah dan didukung adanya nota analisa dan bukti-bukti yang memadai serta didokumentasikan dengan baik. Yang dimaksud dengan bukti-bukti yang memadai adalah:

a. Laporan keuangan nasabah yang menunjukkan perbaikan kinerja usaha

b. Kontrak kerja baru yang diperoleh nasabah

c. Sumber pembayaran lain yang jelas

7. Pembiayaan yang akan dipenjadwalan ulang dianalisis berdasarkan prospek usaha nasabah dan/atau kemampuan membayar sesuai proyeksi arus kas untuk nasabah pembiayaan usaha produktif ataupun non produktif.

8. Pejabat atau pegawai yang melakukan penjadwalan ulang pembiayaan harus berbeda dengan pejabat atau pegawai yang terlibat dalam pemberian pembiayaan.

9. Keputusan penjadwalan ulang pembiayaan harus dilakukan oleh pejabat yang kedudukannya lebih tinggi dari pejabat yang memutuskan pemberian pembiayaan.

10. Dalam hal keputusan pemberian pembiayaan dilakukan oleh pihak yang memiliki kewenangan tertinggi sesuai Anggaran Dasar Bank, maka keputusan penjadwalan ulang pembiayaan dilakukan oleh pejabat yang kedudukannya setingkat dengan pejabat yang memutuskan pembiayaan.

11. Pembiayaan kepada pihak terkait yang dipenjadwalan ulang dianalisis oleh Konsultan Keuangan Independen yang memiliki izin usaha dan reputasi baik.

12. Analisis yang dilakukan oleh bank/Konsultan Keuangan Independen terhadap pembiayaan yang dipenjadwalan ulang dan setiap tahapan dalam pelaksanaan penjadwalan ulang pembiayaan didokumentasikan secara lengkap dan jelas.

13. Penjadwalan ulang pembiayaan dituangkan dalam addendum akad Pembiayaan dan/ atau melakukan akad Pembiayaan yang baru mengikuti karakteristik masing-masing bentuk pembiayaan.

Pokok ketentuan yang ada pada point 5, 6, 7 diatas sesuai dengan SEBI no. 13/18/DPbS tahun 2011 tentang Restrukturisasi Pembiayaan bagi Bank Umum Syariah dan Unit Usaha Syariah juga menerangkan tentang pembentukan satuan kerja khusus dijelaskan bahwa; pertama, pejabat atau pegawai yang melakukan restrukturisasi (rescheduling) pembiayaan harus berbeda dengan pejabat atau pegawai yang terlibat dalam pemberian 
pembiayaan; kedua, keputusan restrukturisasi (rescheduling) pembiayaan harus dilakukan oleh pejabat yang kedudukannya lebih tinggi dari pejabat yang memutuskan pemberian pembiayaan; ketiga, dalam hal keputusan pemberian pembiayaan dilakukan oleh pihak yang memiliki kewenangan tertinggi sesuai anggaran dasar perusahaan, maka keputusan restrukturisasi (rescheduling) pembiayaan dilakukan oleh pejabat yang kedudukannya setingkat dengan pejabat yang memutuskan pemberian pembiayaan.

Rescheduling juga diatur di dalam ketentuan Fatwa Dewan Syariah Nasional (DSN) Majelis Ulama Indonesia (MUI) No. 48 tentang Penjadwalan Kembali Tagihan Murabahah, yang menjelaskan bahwa Lembaga Keuangan Syariah (LKS) boleh melakukan penjadwalan kembali (rescheduling) tagihan murabahah bagi nasabah yang tidak bisa melunasi pembiayaannya sesuai jumlah dan waktu yang telah disepakati, dengan ketentuan:

a. tidak menambah jumlah tagihan yang tersisa;

b. pembebanan biaya dalam proses penjadwalan kembali adalah biaya riil, dan

perpanjangan masa pembayaran harus didasarkan kesepakatan kedua belah pihak.

\subsection{Aplikasi Resheduling Pada Pembiayaan Bermasalah Berakad Murabahah}

Aplikasi rescheduling disesuaikan dengan pendapatan dan kemampuan nasabah yang sedang mengalami kesulitan. Hal tersebut yaitu antara lain:

1. Memperpanjang jangka waktu pembiayaan

Dalam hal ini, nasabah diberikan keringanan dalam masalah jangka waktu pembiayaan misalnya perpanjangan jangka waktu pembiayaan dari 12 bulan menjadi 24 bulan, sehingga nasabah memiliki waktu yang lebih lama untuk mengembalikan kewajibannya.

2. Memperpanjang jangka waktu angsuran

Memperpanjang jangka waktu angsuran tidak banyak berbeda dengan memperpanjang jangka waktu pembiayaan. Dalam hal ini, jangka waktu angsuran pembiayaannya diperpanjang pembayarannya, misalkan dari angsuran 36 kali menjadi 48 kali, maka hal ini tentu saja jumlah angsuran pun menjadi mengecil seiring dengan penambahan waktu angsuran.

Prosedur yang ditempuh oleh nasabah dalam penjadwalan kembali (rescheduling) pembiayaan murabahah dapat digambarkan sebagai berikut: 
Jurnal Ekonomi dan Perbankan Syariah

Vol. 6. No.1, April 2018: 27-48, ISSN (cet): 2355-1755 | ISSN (online): 2579-

6437

39

Bagan 4.1. Prosedur Penjadwalan Kembali (rescheduling)

di Perbankan Syariah

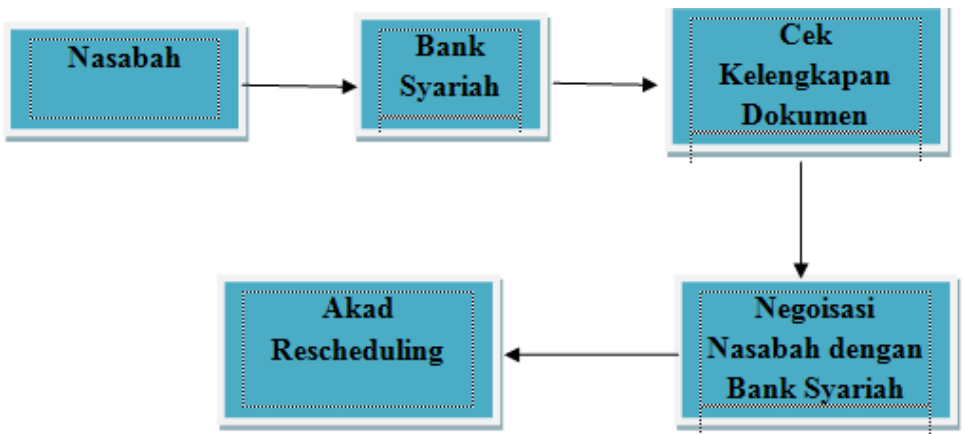

Sumber: Azani, 2016.

Penjelasan pada bagan tersebut, dimulai dengan nasabah mendatangi bank syariah dengan membawa kelengkapan dokumen. Dokumen tersebut diajukan kepada bank syariah melalui divisi pembiayaan murabahah. Kemudian divisi pembiayaan menilai kelengkapan dokumen, jika dokumen yang dinyatakan lengkap maka dilanjutkan dengan negoisasi penjadwalan kembali (rescheduling). Kesepakatan kedua pihak dilanjutkan dengan penandatanganan akad penjadwalan kembali (rescheduling). Kesepakatan kedua pihak dalam akad penjadwalan kembali berarti nasabah mendapat keringanan cicilan pembayaran dan/atau perpanjang masa pembayaran tagihan murabahah.

Secara normal, misalnya nasabah pembiayaan murabahah sebelum akad penjadwalan kembali membayar cicilan selama 24 bulan, setelah akad penjadwalan kembali nasabah membayar cicilan dapat diperpanjang selama 36 bulan. Nasabah yang membayar cicilan murabahah sebelum melakukan penjadwalan kembali dapat diilustrasikan dalam bagan berikut:

Bagan 4.2. Cicilan Nasabah Pembiayaan Murabahah secara Normal

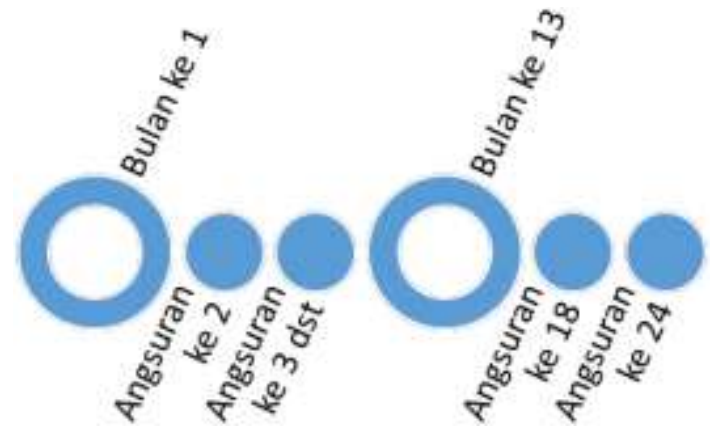

Sumber: Azani, 2016. 
Pada bagan di atas, nasabah pembiayaan murabahah membayar angsuran ke 1 sampai bulan ke 24 berdasarkan akad yang telah disepakati. Dalam perjalanannya, ternyata nasabah mengalami kesulitan keuangan dan mengajukan penjadwalan kembali kepada bank syariah. Setelah akad penjadwalan kembali ditandatangani, kewajiban nasabah dalam membayar cicilan bertambah waktunya menjadi 36 bulan. Hal tersebut dapat diilustrasikan dalam bagan berikut:

\section{Bagan 4.3. Tagihan Penjadwalan Kembali (rescheduling)}

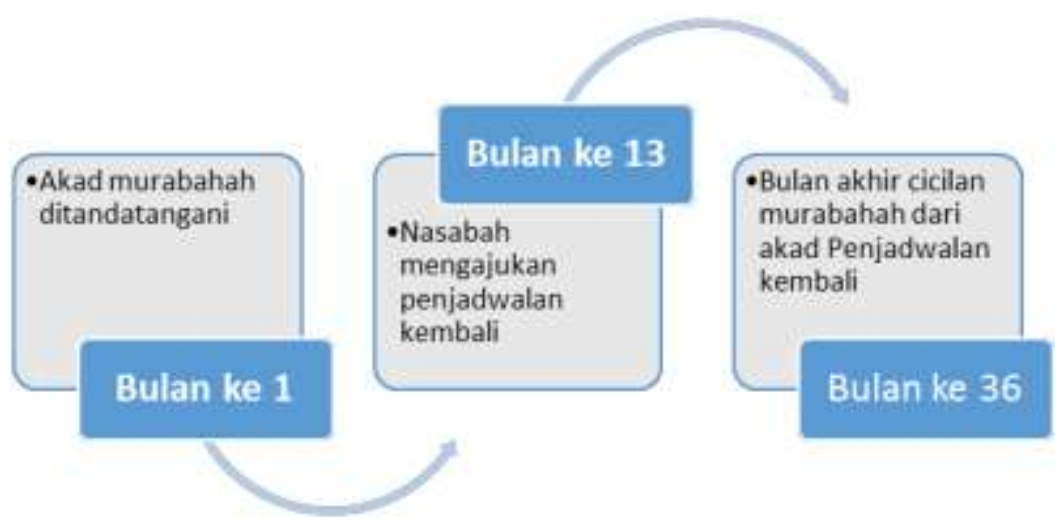

Sumber: Azani, 2016.

Pada bagan tersebut, jangka waktu pembiayaan murabahah berubah yang awalnya hanya 24 bulan, namun pada sebelum bulan ke-13 nasabah mengalami kesulitan, kemudian nasabah mengajukan penjadwalan kembali (rescheduling) kepada bank syariah pada bulan ke-13, jika semua prosedur telah dilakukan termasuk pembuatan akad, maka jangka waktu pembiayaan nasabah akan bertambah misalkan menjadi 36 bulan, pada bulan ke-36 itulah nasabah mengakhiri cicilan pembiayaan murabahah dari akad rescheduling.

Nasabah memiliki waktu membayar kewajibannya yang lebih panjang dalam cicilan pembiayaan murabahah setelah penandatanganan penjadwalan kembali. Namun nasabah dituntut untuk mematuhi kesepakatan yang telah dibuat dengan bank syariah. Bagi nasabah yang tidak mematuhi kesepakatan tersebut, maka bank syariah dapat melakukan langkah-langkah penyelesaian yang dianggap perlu.

Penjadwalan kembali (rescheduling) pembiayaan boleh dilaksanakan atas permohonan secara tertulis dari nasabah. Merujuk kepada permohonan secara tertulis tersebut kepada pihak bank, maka perlu melalui beberapa tingkat (Taqiuddin, 2017, hlm. 180), diantaranya yaitu sebagai berikut:

1. Pengumpulan dan Pengesahan Data Nasabah

Untuk mendapatkan data yang tepat dan relavan, perlu dilakukan kunjungan ke lokasi perdagangan dan jaminan serta didukung informasi yang tepat. Sebelum melakukan penjadwalan kembali, bank syariah terlebih dahulu mencari informasi mengenai masalah yang dihadapi nasabah yang berkaitan. 
Jurnal Ekonomi dan Perbankan Syariah

Vol. 6. No.1, April 2018: 27-40, ISSN (cet): 2355-1755 | ISSN (online): 2579-

6437

| 41

Cara tersebut juga bisa dilakukan dengan berhubung langsung dengan rekan bisnis/perdagangan, surat kabar atau data Bank Indonesia.

2. Menawarkan Pola Penyelamatan

Mengenal pasti masalah yang dialami nasabah dapat memberikan kesimpulan awal yang mana akan dinyatakan kepada nasabah tentang bentuk penyelamatan yang ditawarkan sesuai dengan kemampuan membayar. Bagian pembiayaan perlu menetapkan suatu strategi untuk mengatasi masalah yang dialami nasabah. Penetapan stategi ini terdiri dari 2 pilihan, yaitu:

a. Meneruskan perjanjian; strategi ini dipilih apabila nasabah melihat angsuran dapat diselesaikan dengan baik tanpa tunggakan sama sekali, cara ini dipilih apabila nasabah memiliki harapan agar diselamatkan angsurannya menjadi lebih baik, hingga tanpa tunggakan sama sekali. Disamping karena nasabah memiliki prospek perdapatan yang baik, maka perjanjian ini boleh diteruskan dengan alasan kerjasama dengan pihak bank atau barang jaminan berada pada posisi lemah, yaitu mengalami kesukaran untuk dijual. Sehingga bank perlu berusaha agar nasabah tersebut mampu memulangkan pinjamannya kepada bank demi menjaga likuiditas bank.

b. Menamatkan perjanjian; dipilih karena nasabah tidak berkeinginan untuk meneruskan dengan cara meningkatkan prestasi. Menamatkan perjanjian dapat dilakukan dengan cara melakukan penjualan jaminan. Nasabah yang tidak memberikan kerjasama yang sepatutnya dapat dijadikan alasan bank untuk melakukan jualan jaminan yang diberi. Karena bank pada prinsipnya memerlukan komitmen nasabah untuk mengembalikan pinjaman bank tersebut. Juga didapati nasabah yang telah menggunakan uang pinjaman untuk kepentingan pribadi pada waktu yang sama nasabah tersebut memiliki tunggakan pinjaman dari bank syariah. Apalagi barang jaminan berada pada posisi kuat, maka secepatnya bank harus mengambil tindakan untuk menyelamatkan uang pinjaman dan kepercayaan masyarakat.

3. Proses Analisis Pembiayaan

Penilaian ulang atas pembiayaan-pembiayaan bermasalah yang dilaksanakan dengan melihat keadaan dan prospek pendapatan nasabah pembiayaan murabahah. Jika pendapatan nasabah pembiayaan mempunyai prospek yang baik untuk diteruskan, maka pembiayaan perlu dihitung untuk pelaksanaan penjadwalan ulang. Tujuan analisis pembiayaan adalah untuk menciptakan analisis pembiayaan yang efisien dalam pengambilan keputusan pembiayaan yang tepat.

4. Pemantauan Terhadap Nasabah

a. Memantau informasi mengenai pengurusan nasabah. Bank syariah perlu kerap kali memperhatikan prestasi nasabah dan pendapatan/bisnisnya, karena ini sangat berkait dengan kualitas angsuran yang diberikan oleh nasabah kepada bank. Pemantauan ini dapat dilaksanakan demi melihat komitmen nasabah dalam usahanya 
untuk membayar angsuran seperti sumber dana dan informasi yang diberikan nasabah kepada bank mengenai apa saja yang dirasakan oleh nasabah dalam pendapatannya setelah dilaksanakan penjadwalan ulang (rescheduling).

b. Kunjungan terhadap nasabah. Proses ini penting agar bank dapat lebih mengetahui keadaan nasabah. Dengan melakukan kunjungan ke nasabah, bank dapat melakukan pengesahan informasi yang diberikan nasabah kepada bank, misalnya melalui saudara nasabah. Jika nasabah memiliki bisnis, maka bank dapat memperoleh informasi dari bisnis tersebut seumpamanya yang berada disekitar nasabah. Usaha ini dilakukan untuk memperoleh data yang tepat sebagai bahan melaksanakan penjadwalan ulang (rescheduling) pembiayaan.

Dalam aplikasinya, rescheduling pembiayaan murabahah juga memiliki dokumentasi serta asuransi dengan ketentuan sebagai berikut:

1) Terhadap permohonan penjadwalan ulang pembiayaan yang telah disetujui oleh Komite Penjadwalan Ulang Pembiayaan segara ditegaskan kepada nasabah dengan Surat Penegasan Persetujuan Penjadwalan ulang (SP2R)

2) Apabila nasabah telah menyetujui persyaratan dalam SP2R, maka segera dilakukan pengikatan penjadwalan ulang atau dibuatkan akad/addendum akad penjadwalan ulang pembiayaan beserta dokumennya.

3) Akad pembiayaan dan dokumen lainnya yang berkaitan dengan pelaksanaan penjadwalan ulang pembiayaan harus mempunyai kekuatan hukum.

4) Jangka waktu penutupan asuransi terhadap obyek pembiayaan/agunan harus disesuaikan dengan jangka waktu pembiayaan setelah dilakukan penjadwalan ulang.

5) Pengikatan obyek pembiayaan/agunan harus mengacu pada akad penjadwalan ulang pembiayaan yang baru.

\subsection{Pelaksanaan Resheduling Pembiayaan Murabahah Di Bank Syariah Menurut Hukum Islam dan Fatwa DSN MUI}

Sebagaimana telah diatur dalam Fatwa Dewan Syariah Nasional Majlis Ulama Indonesia No. 48/DSN-MUI/II/2005 tentang Penjadwalan Ulang Tagihan Murabahah. Terdapat syarat-syarat nasabah penjadwalan ulang sekiranya:

a. Potensi usaha/perdagangan nasabah memiliki prospek yang baik

b. Nasabah memiliki kemampuan untuk menjalankan perdagangannya/usahanya tetapi mengalami sedikit masalah dalam waktu pengembalian kewajibannaya

c. Adanya masalah dalam aliran uang perdagangan/usaha nasabah

d. Pembiayaan yang diberikan tetap.

Penjadwalan ulang (rescheduling) pembiayaan murabahah dilaksanakan oleh bank syariah sebagai bentuk perkhidmatan terhadap nasabah 
Jurnal Ekonomi dan Perbankan Syariah

Vol. 6. No.1, April 2018: 27-40, ISSN (cet): 2355-1755 | ISSN (online): 2579-

6437

43

yang mengalami kesulitan membayar kewajibannya. Penjadwalan ulang bertujuan memberikan keringanan kepada nasabah dalam angsuran pembiayaan murabahah. Nasabah berpeluang memperoleh potongan berupa pengurangan pembayaran angsuran. Potongan diberikan kepada nasabah bersandarkan kepada ketetapan dalam bank syariah, tapi bank tidak memberikan kepastian tentang potongan kewajiban pembiayaan murabahah, hanya menyatakan bahwa dalam praktik mereka dapat memberikan potongan atau tidak berdasarkan ketetapan dalam bank pada saat analisis kemampuan nasabah dalam membayar angsuran.

Dalam Fatwa Dewan Syariah Nasional (DSN) Majelis Ulama Indonesia (MUI) No. 48 tentang Penjadwalan Kembali Iagihan Murabahah, yang menjelaskan bahwa Lembaga Keuangan Syariah (LKS) boleh melakukan penjadwalan kembali (rescheduling) tagihan murabahah bagi nasabah yang tidak bisa melunasi pembiayaannya sesuai jumlah dan waktu yang telah disepakati, dengan ketentuan:

a. tidak menambah jumlah tagihan yang tersisa;

b.pembebanan biaya dalam proses penjadwalan kembali adalah biaya riil, dan

c. perpanjangan masa pembayaran harus didasarkan kesepakatan kedua belah pihak

Ketetapan tidak menambah jumlah sisa hutang menjadi intipati dalam menentukan penjadwalan ulang. Jumlah angsuran nasabah sebelum dan sesudah penjadwalan ulang adalah sama. Jumlah angsuran yang lebih banyak atau berlebih sama dengan riba.

Ketentuan lainnya pembebanan biaya dalam proses penjadwalan ulang adalah biaya riil. Biaya riil yang dimaksudkan adalah biaya administrasi. Denda tidak dimasukkan ke dalam biaya riil, karena dalam penjadwalan ulang sebenarnya tidak ada denda. Penambahan biaya riil dalam penjadwalan ulang dibenarkan hukum Islam. Penambahan biaya yang dilarang adalah biaya yang mengarah pada keuntungan bank seperti denda karena keterlambatan dan biaya penambahan pembayaran akibat dari penangguhan pembayaran utang murabahah. Penambahan denda keterlambatan tersebut tidak dibenarkan dalam hukum Islam karena termasuk riba. Disini riba berlaku antara bank dan nasabah. Ketidakmampuan nasabah membayar tidak dapat dikenakan denda karena nasabah dalam kesulitan. Keuntungan yang diperoleh dari denda nasabah sebagai bentuk kedzaliman terhadap kesulitan orang lain.

Berdasarkan penelitian Muhammad Taqi Usmani (2001) menyatakan bahwa pihak bank tidak harus mengenakan denda terhadap nasabah yang gagal membayar pada waktu tempo yang telah disepakati, karena hal tersebut sama saja seperti konsep bunga yang diamalkan dalam angsuran. (hlm. 58)

Ajaran Islam mengacu pada Al-Qur'an dan hadits Nabi SAW, mengakui kemungkinan berlakunya utang-piutang dalam perdagangan atau karena keperluan mendesak guna memenuhi keperluannya. Allah SWT memerintahkan kepada kita untuk berkomitmen terhadap akad yang telah 
disepakati bersama, sebagaimana firman Allah SWT: "wahai orang-orang yang beriman, penuhilah serta sempurnakanlah perjanjian-perjanjian..” (Q.S Al-Maidah [5] : 1), berdasarkan penjelasan ayat tersebut, maka dapat dipahami bahwa para pihak yang terkait dalam suatu perjanjian wajib memenuhi segala ketetapan yang telah disepakati. Karena itu nasabah wajib memenuhi kewajibannya, yaitu membayar utangnya sebagaimana tempo yang telah ditentukan dalam perjanjian yang dibuat.

Dalam mengatasi pembiayaan bermasalah yang berakad murabahah, bank syariah melakukan cara rescheduling untuk nasabah yang mengalami penurunan angsuran. Hal ini sesuai dengan firman Allah SWT: "dan jika yang berhutang itu sedang mengalami kesempitan hidup, maka berilah tempo hingga ia lapang hidupnya" (Q.S. Al-Baqarah [2] :2 ).

Maka berdasarkan dalil tersebut, dapat ditarik kesimpulan bahwa untuk bank syariah dalam melaksanakan rescheduling pembiayaan murabahah yaitu dengan cara memberikan tempo waktu sehingga nasabah berkelapangan, dengan penangguhan atau penjadwalan pembayaran ulang tersebut, diharapkan nasabah mempunyai kemampuan membayar kembali kewajibanya sehingga lunas hutang tersebut. Kemampuan untuk membayar kembali disebabkan karena pendapatan atas hasil usaha nasabah dapat berjalan sebagaimana harusnya setelah penjadwalan ulang. Pemberian tempo waktu yang dimaksudkan adalah penambahan tempo waktu pembiayaan tanpa adanya biaya yang dibebani kepada nasabah. Ini karena dalam keadaan seperti ini, nasabah sedang merasakan kesukaran dalam membayar tetapi pihak bank memberikan biaya dalam penjadwalan ulang dan hal ini dapat menambah beban nasabah.

Kemudian dalam kasus pembiayaan bermasalah yang berlaku setelah penjadwalan ulang dilakukan, maka tindakan yang dapat dilakukan oleh bank syariah ialah mengkonversi akad pembiayaan murabahah menjadi pembiayaan qardh. Artinya bank tidak mendapatkan bayaran keuntungan dari nasabah tetapi hanya pembayaan pokok utang saja. Hal ini lebih baik untuk menyelamatkan uang pendeposit yang telah diberikan kepada nasabah peminjam.

\section{KESIMPULAN}

Proses rescheduling pada pembiayaan bermasalah yang berakad murabahah disesuaikan dengan pendapatan dari hasil usaha nasabah yang sedang mengalami kesulitan, yaitu diantaranya memperpanjang jangka waktu pembiayaan dan angsuran dengan kriteria nasabah: mengalami penurunan kemampuan membayar, memiliki prospek usaha yang baik, dan mampu memenuhi kewajiban setelah rescheduling.

Dalam pengaplikasian rescheduling pembiayaan bermasalah berakad murabahah, bank syariah harus menerapkan ketentuan dari Fatwa DSN MUI yaitu diantarnya tidak boleh menambah jumlah tagihan yang tersisa, pembebanan biaya dalam proses penjadwalan kembali adalah biaya riil, dan 
Jurnal Ekonomi dan Perbankan Syariah

Vol. 6. No.1, April 2018: 27-48, ISSN (cet): 2355-1755 | ISSN (online): 25796437

45

perpanjangan masa pembayaran harus didasarkan kesepakatan kedua belah pihak.

Pihak bank tidak harus mengenakan denda terhadap nasabah yang gagal membayar pada waktu tempo yang telah disepakati, karena hal tersebut sama saja seperti konsep bunga yang diamalkan dalam angsuran (riba). Kemudian dalam kasus pembiayaan bermasalah yang berlaku setelah penjadwalan ulang dilakukan, maka tindakan yang dapat dilakukan oleh bank syariah ialah mengkonversi akad pembiayaan murabahah menjadi pembiayaan qardh, hal ini lebih baik untuk menyelamatkan uang pendeposit yang telah diberikan kepada nasabah peminjam.

\section{DAFTAR PUSTAKA}

Abdullah, T. (2012). Bank dan Lembaga Keuangan. Jakarta: PT Raja Grafindo Persada.

Ahmed, H. (2014). Islamic Banking and Shari'ah Complience: A Product Development Perspective. Journal of Islamic Finance - IIUM Institute of Islamic Banking and Finance - Durham University Business School, The United Kingdom , 3, 18.

Ali, S. d. (2015). Efektifitas Penyelesaian Pembiyaan Murabahah Bermasalah di BPRS Metro Madani Kota Metro Tahun 2014. AZKIYA - Junal Hukum dan Ekonomi Syariah, 11.

Antonio, M. S. (2006). Dasar Dasar Manajemen Bank Syariah. Jakarta: Pustaka Alfabeta.

Ascarya. (2007). Akad dan Produk Bank Syariah. Jakarta: PT Rajagrafindo Persada.

Azani, T. H. (2016). Penjadwalan Kembali (rescheduling) Tagihan Murabahah di Bank Syariah Berdasarkan Hukum Islam. Perspektif Hukum .

Baits, A. N. (2015, Mei 4). Aturan Indah tentang Utang Piutang. Retrieved Desember 29, 2017, from Konsultasi Syariah: https://konsultasisyariah.com/24276-aturan-indah-tentang-utangpiutang

Buchori. (2004). Standarisasi Akad Bagi Perbankan Syariah. Jakarta: Direktoral Perbankan Syariah, Bank Indonesia.

Hermansyah. (2011). Hukum Perbankan Nasional Indonesia. Jakarta: Kencana.

Hilyatin, N. d. (2016). Strategi Penyelamatan Pembiayaan Bermasalah Pada Pembiayaan Murabahah . Eljizya, 4.

Idroes, F. N. (2011). Manajemen Risiko Perbankan. Jakarta: PT. Raja Grafindo Persada.

Ismail. (2011). Perbankan Syariah. Jakarta: Kencana Prenada Media Group. 
46 | Andini Salamah: Pola Resecheduling Pada Pembiayaan Bermasalah Berakad Murabahah Di Bank Syariah

Janwari, D. Y. (2015). Lembaga Keuangan Syariah. Bandung: PT Remaja Rosdakarya.

Karim, A. A. (2010). Bank Islam: Analisis Fiqh dan Keuangan. Jakarta: PT Rajagrafindo Persada.

Muhammad. (2008). Manajemen Pembiayaan Bank Syariah. Yogyakarta: UPP AMP YKPN..

MUI, D. S. (2010). Himpunan Fatwa Dewan Syariah Nasional MUI. Jakarta: Gaung Persada Press.

OJK. (2017, Juni). Statistika Perbankan Syariah. Retrieved September 15, 2017, from www.ojk.go.id: http://www.ojk.go.id/id/kanal/syariah/datadan-statistik/statistik-perbankan-syariah/Pages/Statistik-PerbankanSyariah-\%E2\%80\%93-Juni-2017.aspx

RI, A. T. (2009, Juli 16). Tafsir Depag RI. Retrieved Desember 29, 2017, from Rumah Islam: https://rumahislam.com/sunan-abu-dawud/559-tafsirdepag-ri

Rustam, B. R. (2017). Manajemen Risiko: Prinsip, Penerapan, dan Penelitian. Jakarta: Salemba Empat.

S.P.Hasibuan, M. (2009). Dasar Dasar Perbankan. Jakarta: PT Bumi Aksara.

Satyawan, N. E. (2014). Evaluasi Tingkat Risiko Pembiayaan Murabahah. Jurnal Ilmu Manajemen , 2 No. 4.

Sjahdeini, S. R. (2010). Perbankan Islam dan Kedudukannya dalam Tata Hukum Perbankan. Jakarta: Grafiti.

Sugiono. (2009). Metode Penelitian Kuantitatif dan Kualitatif. Bandung: Alfabeta.

Sutedi, A. (2009). Perbankan Syariah: Tinjauan dan Beberapa Segi Hukum. Bogor: Ghalia Indonesia.

Suyatno, T. (2007). Dasar Dasar Perkreditan. Jakarta: PT Gramedia Pustaka Utama.

Swartz, N. P. (2012). Risk management in Islamic Banking. Academic Journals - African Journals of Bussiness Management .

Taqiuddin, A. M. (2017). Penjadwalan Ulang Pembiayaan Mikro Murabahah di Bank Syariah Mandiri Cabang Dumai Provinsi Riau. Jurnal Ilmiah Islam Futura - Vol. 17, No. 1

Tratmono, A. S. (2004). Kajian Tentang Konsep Kesehatan Bagi Bank Syariah. Jakarta: Bank Indonesia..

Usmani, M. T. (2001). An Introduction to Islamic Finance. Resolution No. 53 Vth Annual Session, Jeddah, Journal No. $6,01$.

Wangsawidjaja. (2012). Pembiayaan Bank Syariah. Jakarta: PT Gramedia.

Wiroso. (2005). Penghimpunan Dana dan Distribusi Hasil Usaha Bank Syariah. Jakarta: Grasindo.

Wibowo, E. (2005). Mengapa Memilih Bank Syariah? Bogor: Ghalia Indonesia.

Yumanita, A. d. (2005). Bank Syariah (Gambaran Umum). Jakarta: Pusat Pendidikan dan Studi Kebanksentralan.

Zulkifli, S. (2007). Panduan Praktis Transaksi Perbankan Syariah. Jakarta: Zikrul Hakim. 